\title{
Article \\ Fabrication and Characterization of a Marine Wet Solar Cell with Titanium Dioxide and Copper Oxides Electrodes
}

\author{
Htoo Nay Wunn * (D), Shinichi Motoda and Motoaki Morita \\ Department of Marine Electronics and Mechanical Engineering, School of Marine Technology, Tokyo University \\ of Marine Science and Technology, 2-1-6 Etchujima, Koto-ku, Tokyo 135-8533, Japan; \\ motoda@kaiyodai.ac.jp (S.M.); morita@kaiyodai.ac.jp (M.M.) \\ * Correspondence: htoonaywunn@gmail.com; Tel.: +81-70-4382-6983
}

check for

updates

Citation: Wunn, H.N.; Motoda, S.; Morita, M. Fabrication and Characterization of a Marine Wet Solar Cell with Titanium Dioxide and Copper Oxides Electrodes. Catalysts 2022, 12, 99. https://doi.org/ $10.3390 /$ catal12010099

Academic Editors: Paola Semeraro and Roberto Comparelli

Received: 24 December 2021

Accepted: 13 January 2022

Published: 15 January 2022

Publisher's Note: MDPI stays neutral with regard to jurisdictional claims in published maps and institutional affiliations.

Copyright: (C) 2022 by the authors. Licensee MDPI, Basel, Switzerland. This article is an open access article distributed under the terms and conditions of the Creative Commons Attribution (CC BY) license (https:// creativecommons.org/licenses/by/ $4.0 /)$.

\begin{abstract}
One of the effective ways of utilizing marine environments is to generate energy, power, and hydrogen via the effect of photocatalysts in the seawater. Since the ocean is vast, we are able to use its large area, but the power generation system must be of low cost and have high durability against both force and corrosion. In order to meet those requirements, this study focuses on the fabrication of a novel marine wet solar cell composed of a titanium dioxide photoanode and a copper oxide photocathode. These electrodes were deposited on type 329J4L stainless steel, which possesses relative durability in marine environments. This study focuses on the characterization of the photocatalytic properties of electrodes in seawater. Low-cost manufacturing processes of screenprinting and vacuum vapor deposition were applied to produce the titanium dioxide and copper oxides electrodes, respectively. We investigated the photopotential of the electrodes, along with the electrochemical properties and cell voltage properties of the cell. X-ray diffraction spectroscopy (XRD) of the copper oxides electrode was analyzed in association with the loss of photocatalytic effect in the copper oxides electrode. Although the conversion efficiency of the wet cell was less than $1 \%$, it showed promising potential for use in marine environments with low-cost production. Electrochemical impedance spectroscopy (EIS) of the cell was also conducted, from which impedance values regarding the electrical properties of electrodes and their interfaces of charge-transfer processes were obtained. This study focuses on the early phase of the marine wet solar cell, which should be further studied for long-term stability and in actual marine environmental applications.
\end{abstract}

Keywords: titanium dioxide; copper oxides; marine wet solar cell; photocatalysts; seawater electrolyte

\section{Introduction}

\subsection{Background}

Since prehistoric times, we have utilized the marine environment and drawn benefits from it-especially in the areas of transportation and nutrition. Today, it has gained much attention not only for those areas, but also for its natural resources, such as oil and gas reserves. We have been able to produce electrical energy from the sustainable and renewable energy resources of the marine environment, such as tidal waters, waves, and wind power, as well as solar energy from floating solar farms. To counter the effects of global warming and climate change caused by the release of greenhouse gases and the exhaustion of fossil-related energy resources, it is vitally important to increase the use of alternative, renewable, and relatively clean energy resources (e.g., solar, wind, hydro, and geothermal) in order to meet the high demand for energy and to secure the development goals of humanity. Among those energy sources, solar energy is regarded as the most abundantly available and virtually infinite energy source [1,2]. Very large solar farms require a substantial utilization of land resources, with an adverse impact on the environment, causing deforestation, changes in soil quality, loss of agricultural lands and wastelands, and microclimate change [3]. To remedy those problems, the study and 
construction of floating solar farms has become an interesting topic in the photovoltaic industry. Hybrid floating solar farms in conjunction with wind turbines are installed near coastal areas. However, most of the studies on floating solar farms are focused on the installation design of the already commercially available solar panels above the water surface. As a way to consider an alternative method, and to effectively utilize the marine environment, we included the use of seawater as the electrolyte in this study of the marine wet solar cell. In this research, we consider the early phase of characterization of a novel marine wet solar cell using two photocatalyst electrodes and a seawater electrolyte.

\subsection{Titanium Dioxide Photocatalyst}

Titanium dioxide has been widely studied for its n-type semiconductor photocatalytic activity, having a wide band gap and higher resistance to photocorrosion [4]; it has been used as a catalyst for water splitting, and in dye-sensitized solar cells [5,6]. Titanium dioxide is naturally observed in three main polymorphs: two tetragonal structures of rutile, anatase, and orthorhombic brookite [7-11]. There are reportedly other phases of titanium dioxide at high pressures $[12,13]$. Rutile is a thermodynamically stable phase, but anatase and brookite phases are metastable. Moreover, the brookite phase is suboptimal for film formation $[7,11,14]$. Many studies and industrial uses of titanium dioxide have been reported, such as hydrogen production by electrolysis of water, dye-sensitized solar cells, wastewater treatment, cosmetics, and biomedicinal self-sterilizing coatings [5,15-22]. Research concerning the film-forming process of titanium dioxide has been conducted, including rapid thermal oxidation, chemical conversion methods, dip-coating, and the sol-gel method [19,23-25].

\subsection{Copper Oxides Photocatalysts}

Copper oxides, among metal oxides, have been attracting a lot of research interest due to their p-type semiconductor photocatalytic characteristics [26-28]. Copper has two main types of oxide: copper(I) oxide, or cuprous oxide $\left(\mathrm{Cu}_{2} \mathrm{O}\right)$; and copper(II) oxide, or cupric oxide $(\mathrm{CuO})$. Both oxides show p-type semiconductor characteristics, but their crystal structures and band gaps are different. $\mathrm{Cu}_{2} \mathrm{O}$ shows a cubic crystal structure, and thin film $\mathrm{Cu}_{2} \mathrm{O}$ is used as an absorber layer in solar cells [26-28]. Mainly monoclinic $\mathrm{CuO}$ exhibits higher physical and chemical properties, electrochemical activity, thermal conductivity, and stability in solutions, as well as lower production cost [29,30]. Research studies concerning $\mathrm{CuO}$ include $\mathrm{CuO}$ as a photocatalyst for the removal of pollutants, and for water splitting [31,32]. Copper oxides have been synthesized electrochemically, physically, and chemically, such by spray pyrolysis, the sol-gel method, chemical vapor deposition, pulsed laser deposition, sputtering, and electrochemical deposition [33-38].

\subsection{Study of the Marine Wet Solar Cell}

This study aimed to fabricate and characterize a novel type of marine wet solar cell that consists of a titanium dioxide photoanode and a copper oxides photocathode. A wet solar cell is a type of light-harvesting solar cell that uses aqueous solutions as electrolytes. A marine wet solar cell calls for the use of seawater as an electrolyte. The purpose of this type of solar cell is to be used effectively in marine environments, and it has the potential to be used to supply power to offshore structures, or even (in future) to autonomous ships. The benefit of this type of solar cell is that because seawater is used as an electrolyte, the cell does not particularly need the cell walls to contain the electrolyte.

In this study, the film-forming of titanium dioxide was processed by the screenprinting method, using titanium dioxide paste. The screen-printing method is convenient, and can control the thickness and porosity of the titanium dioxide film [39]. This study utilized a titanium dioxide paste consisting of rutile and anatase phases. The photocatalytic activity of titanium dioxide is enhanced by the formation of a heterojunction of rutile and anatase layers in the titanium dioxide film [40]. On the other hand, many studies have been conducted concerning the use of platinum as a cathodic counter-electrode. There have been 
numerous studies on cathodes that can be used for this type of cell. Many such studies have concerned the use of platinum electrodes. If a platinum electrode is used as the cathode, the cost-to-cell-efficiency ratio makes it relatively unrealistic for deployment in vast oceanic areas. Passivated stainless steel can be considered to be a cost-effective alternative, but its photocatalytic activity is low and its tendency for corrosion becomes higher in seawater. Therefore, this study introduced the use of stainless steel on which a p-type semiconductor film was deposited. Although there are many p-type semiconductor metal oxides, this study utilized p-type semiconductor copper oxides, since high-temperature oxidation of the vacuum-deposited copper film on the stainless steel substrate shows photocatalytic activity at a relatively low cost compared to a platinum counter-electrode [41]. In this study, a thin film of copper oxides was formed as a part of a low-cost fabrication process by the vacuum vapor deposition in conjunction with a heat treatment process [42].

$\mathrm{TiO}_{2}-\mathrm{Cu}_{2} \mathrm{O}$ heterojunction solar cells were studied by Michele Pavan et al., in a study where both metal oxide layers were produced by the spray pyrolysis method, and silver was used as a back contact [33]. However, there are no reported studies of a marine wet solar cell with $\mathrm{TiO}_{2}$ and copper oxides electrodes and seawater as the electrolyte. This study emphasizes the fabrication of a novel type of marine wet solar cell—with a titanium dioxide photoanode, a copper oxides photocathode, and seawater as the electrolyte-and its photoelectrical characterization and analysis. The schematic presentation of the proposed solar cell is shown in Figure 1.

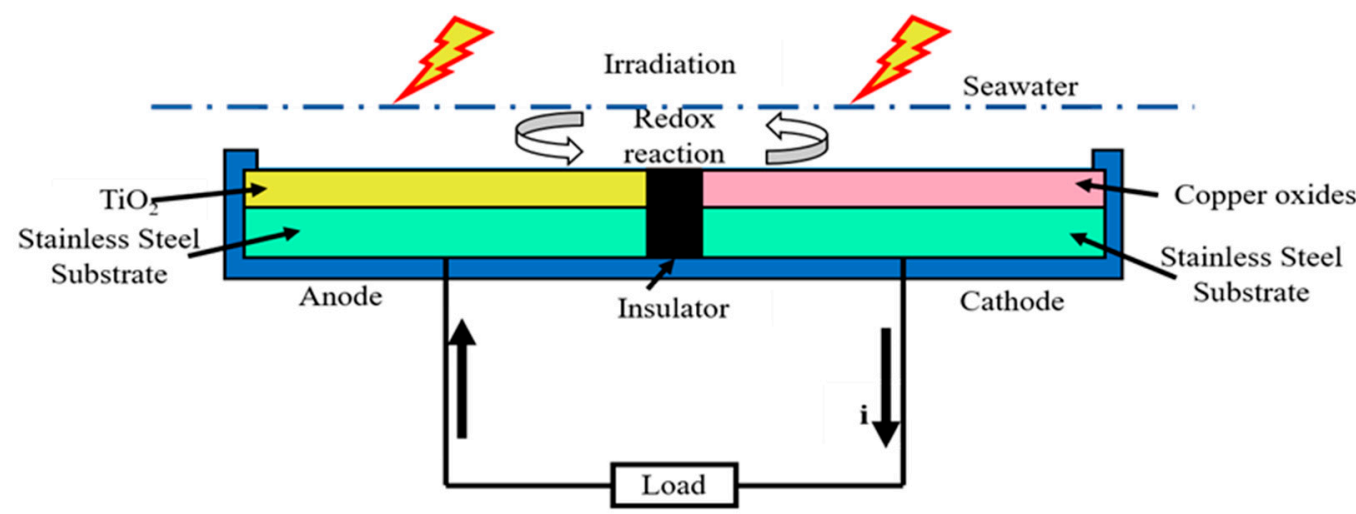

Figure 1. Schematic representation of the proposed marine wet solar cell.

\section{Results}

\subsection{Photocatalytic Properties of Each Electrode}

Photopotential measurement of each electrode was carried out in order to confirm their semiconductor properties and to figure out the reaction potential of each electrode. Figure 2 presents the two graphs of the photopotential of each electrode and the voltage of the cells over time. When light was irradiated, the photocatalytic effect of each electrode caused the reactions at the surface of each electrode. For the $\mathrm{TiO}_{2}$ electrode, the surface oxidation reaction can be represented as follows:

$$
2 \mathrm{H}_{2} \mathrm{O}+2 \mathrm{e} \rightarrow \mathrm{H}_{2}+2 \mathrm{OH}^{-}
$$

which gives the standard electrode potential of $-820 \mathrm{mV}$ versus the standard hydrogen electrode (SHE) [40].

The reduction reaction at the surface of the copper oxides electrode can be expressed as follows:

$$
4 \mathrm{OH}^{-} \rightarrow \mathrm{O}_{2}+2 \mathrm{H}_{2} \mathrm{O}+4 \mathrm{e}^{-}
$$

with the standard electrode potential of $400 \mathrm{mV}$ versus SHE [43]. 


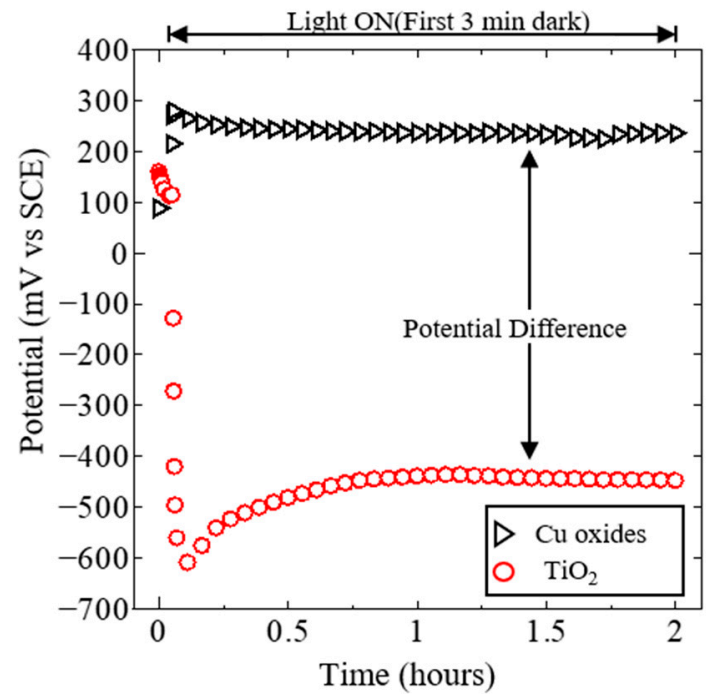

(a)

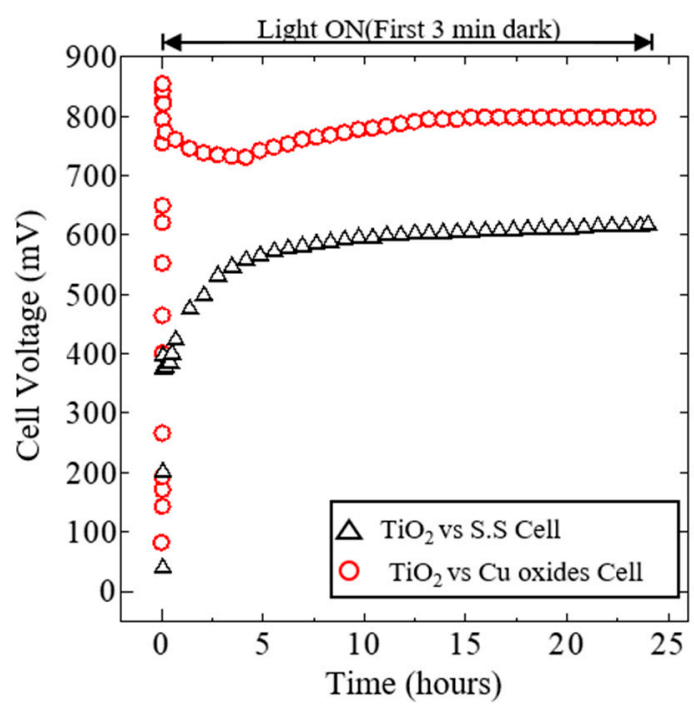

(b)

Figure 2. (a) Photopotential of the $\mathrm{TiO}_{2}$ and copper oxides electrodes, and (b) cell voltage over a $24 \mathrm{~h}$ period of combined $\mathrm{TiO}_{2}-\mathrm{Cu}$ oxides cell and $\mathrm{TiO}_{2}$-stainless steel cell.

As shown in Figure 2a, just after irradiation of the $\mathrm{TiO}_{2}$ electrode, the photopotential decreased swiftly to below $-600 \mathrm{mV}$ (vs SCE), but the values were rebounded back to $-500 \mathrm{mV}$, and became stable throughout the $2 \mathrm{~h}$ measurement. This confirms the n-type semiconductor characteristics of titanium dioxide. The reason for the rebounded shift towards the increase in the photopotential of the $\mathrm{TiO}_{2}$ electrode is still under research.

The irradiation of the copper oxides electrode caused the electrode to activate its p-type photocatalytic semiconductor characteristics. The potential was increased to $300 \mathrm{mV}$, but dropped by $\sim 50 \mathrm{mV}$ and became stable in the region of $250 \mathrm{mV}$ for the entire $2 \mathrm{~h}$ measurement period. This drop was the result of copper(I) oxide $\left(\mathrm{Cu}_{2} \mathrm{O}\right)$ still remaining during the heat treatment process, which underwent oxidation in the seawater during the irradiation testing (Figure 3). This can be seen more clearly in the XRD analysis of the copper oxides electrode shown in Section 3. By coupling these two electrodes, a cell voltage of $800 \mathrm{mV}$ could be obtained.

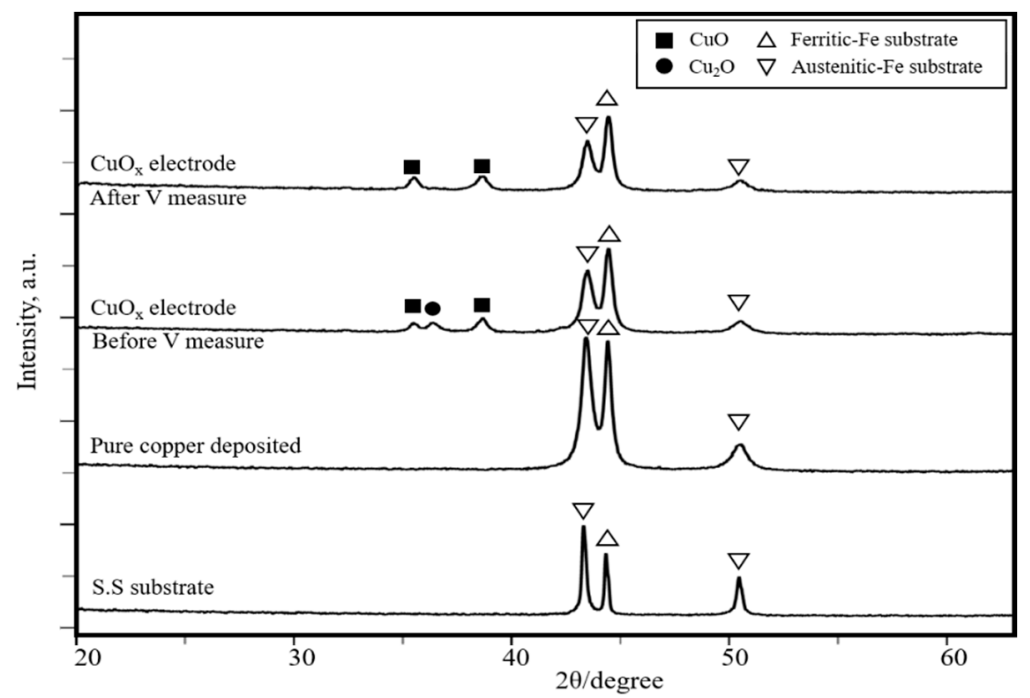

Figure 3. XRD patterns of stainless steel substrate, pure $\mathrm{Cu}$-deposited substrate, $\mathrm{Cu}$ oxides electrode before photopotential measurement, and $\mathrm{Cu}$ oxides electrode after photopotential measurement. 
The cell voltage over a $24 \mathrm{~h}$ period of the $\mathrm{TiO}_{2}$-copper oxides cell and a $\mathrm{TiO}_{2}-$ passivated stainless steel cell can be seen in Figure $2 \mathrm{~b}$. In the $\mathrm{TiO}_{2}$-copper oxides cell, the voltage went up to $850 \mathrm{mV}$ just after irradiation, but then dropped until it reached just below $750 \mathrm{mV}$ at $5 \mathrm{~h}$, after which the photopotential increased once more. After the first $12 \mathrm{~h}$, the cell voltage became stable at $800 \mathrm{mV}$. In the $\mathrm{TiO}_{2}$-stainless steel cell, the cell voltage went up to $400 \mathrm{mV}$ after irradiation, and then slowly increased until it reached $600 \mathrm{mV}$, becoming stable at this voltage value until the end of the measurement. During a $24 \mathrm{~h}$ measurement, there was no drop in the cell voltage in the $\mathrm{TiO}_{2}-$ S.S. cell, but a decrease in voltage was observed in the $\mathrm{TiO}_{2}$-copper oxides cell. By comparing the results of these two cells, it can be concluded that the drop in cell voltage was mainly caused by the defects in the copper oxides electrode. The cause of photocatalytic reduction at the copper oxides electrode will be discussed in Section 3.

\subsection{X-ray Diffraction Analysis of Copper oxides Electrode}

In order to better understand the decrease in cell voltage in the measurement of the $\mathrm{TiO}_{2}$-copper oxides cell, XRD analysis was performed on the copper oxides electrode before and after photopotential measurement. Figure 3 shows the XRD profiles of the base stainless steel substrate, pure copper-deposited substrate, and copper oxides electrodes before and after photopotential measurement. In the analysis of the copper-deposited substrate, the peaks of deposited pure copper were superpositioned with that of the substrate at $2 \theta=43^{\circ}$ and $51^{\circ}$ [44].

Two peaks of copper(II) oxide $(\mathrm{CuO})$ were detected between $2 \theta=35^{\circ}$ and $40^{\circ}$ in the copper oxides electrode. The electrode before photopotential measurement showed the peak of copper(I) oxide $\left(\mathrm{Cu}_{2} \mathrm{O}\right)$, but this peak disappeared after the photopotential measurement.

\subsection{Power Density-Cell Voltage Characteristics of Each Cell}

The power density versus cell voltage measurement of four types of electrodes under irradiation is shown in Figure 4. The comparative short-circuit current density $\left(\mathrm{J}_{\mathrm{sc}}\right)$, opencircuit voltage $\left(\mathrm{V}_{\mathrm{oc}}\right)$, maximum power density $\left(\mathrm{P}_{\max }\right)$, and fill factor $(\mathrm{FF})$ values of the cells can be seen in Table 1.

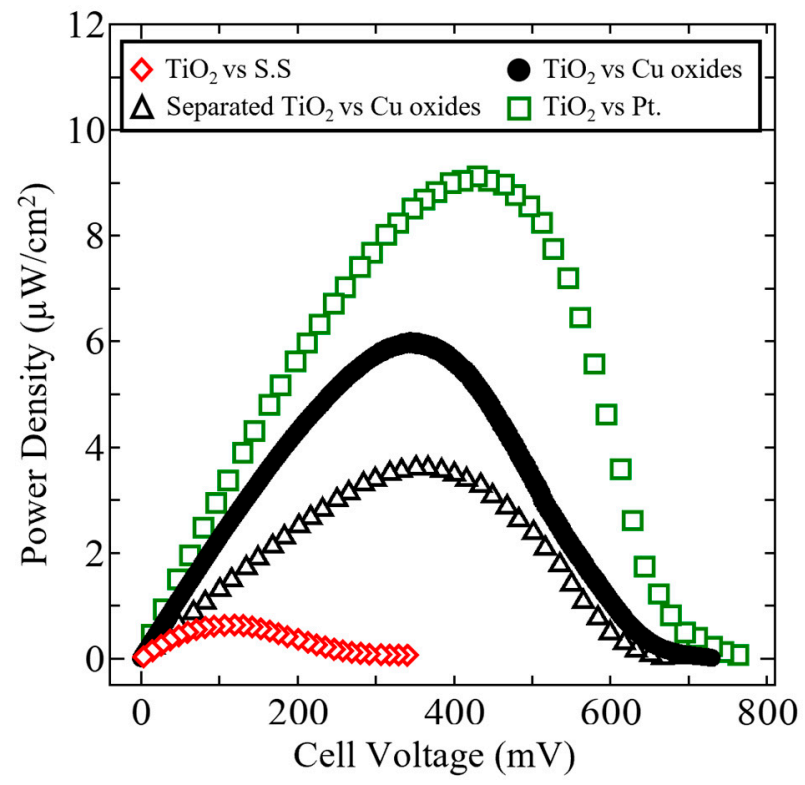

Figure 4. Power vs. cell voltage $(\mathrm{P}-\mathrm{V})$ of four types of cells. 
Table 1. P, I, and V values of the cells under irradiation.

\begin{tabular}{ccccc}
\hline Cells & $\mathbf{J}_{\mathbf{s c}}\left(\boldsymbol{\mu} \mathbf{A} / \mathbf{c m}^{\mathbf{2}}\right)$ & $\mathbf{V}_{\mathbf{o c}}(\mathbf{m V})$ & $\mathbf{P}_{\mathbf{m a x}}\left(\boldsymbol{\mu W} / \mathbf{c m}^{\mathbf{2}}\right)$ & $\mathbf{F F}(\mathbf{\%})$ \\
\hline Separated $\mathrm{TiO}_{2}-\mathrm{Cu}$ oxides & 17.96 & 727.4 & 4.20 & 32.15 \\
Combined $\mathrm{TiO}_{2}-\mathrm{Cu}$ oxides & 23.44 & 730.3 & 5.96 & 34.82 \\
$\mathrm{TiO}_{2}-$ stainless steel & 11.20 & 561.6 & 0.64 & 10.20 \\
$\mathrm{TiO}_{2}$-platinum & 31.68 & 764.1 & 9.11 & 37.63 \\
\hline
\end{tabular}

In the case of the cell with $\mathrm{TiO}_{2}-$ S.S., the maximum power was the lowest, at $0.6 \mu \mathrm{W} / \mathrm{cm}^{2}$, which is $10 \%$ of that of the $\mathrm{TiO}_{2}$-copper oxides combined cell. Moreover, the fill factor (FF) is very much lower (at $10.2 \%$ ) when compared with other cells. This is considered to be due to the lower photocatalytic effect of stainless steel, which contributes to the lower band gap for light harvesting.

In the cells of combined $\mathrm{TiO}_{2}-\mathrm{Cu}$ oxides and separated $\mathrm{TiO}_{2}-\mathrm{Cu}$ oxides, the maximum power density was higher in the combined cell, at $6 \mu \mathrm{W} / \mathrm{cm}^{2}$. Although $\mathrm{V}_{\mathrm{oc}}$ in both cells was around $730 \mathrm{mV}$, the current density of the combined cell was higher than that of separated cell. When the electrodes were placed a few centimeters apart in the seawater, the maximum power was reduced to $4 \mu \mathrm{W} / \mathrm{cm}^{2}$.

The maximum power density of the combined $\mathrm{TiO}_{2}-\mathrm{Cu}$ oxides cell was two-thirds of that of the $\mathrm{TiO}_{2}$-platinum cell. The maximum power density of the $\mathrm{TiO}_{2}$-platinum cell was the highest among the cells, at $9 \mu \mathrm{W} / \mathrm{cm}^{2}$. Even with the highest maximum power output of the $\mathrm{TiO}_{2}$-platinum cell, the conversion efficiency from light to electrical energy was less than $1 \%$, and the fill factor was $\sim 35 \%$. Using the results obtained from the Tafel regions of the $\mathrm{P}-\mathrm{V}$ graph, the EIS analysis was performed for the charge-transfer resistance of the electrodes.

\subsection{Electrochemical Properties of Electrodes by EIS Analysis}

EIS analysis was conducted in order to identify the charge-transfer process in the electrolyte-electrode interface, and to determine the electrical properties of the electrodes [45-47]. Knowing the electrical properties helped us to reduce the resistance parameters of the cell. Figure 5 shows the impedance spectra of two types of cell: $\mathrm{TiO}_{2}-$ $\mathrm{Cu}$ oxides, and $\mathrm{TiO}_{2}$-platinum. The equivalent circuits were constructed using a simple curve-fitting method for $\mathrm{TiO}_{2}-\mathrm{Cu}$ oxides and $\mathrm{TiO}_{2}$-platinum cells, in order to identify the impedance values of those cells $[45,46]$. The impedance values of $\mathrm{TiO}_{2}-\mathrm{Cu}$ oxides cells fluctuated in the low-frequency region of the plot. An equivalent circuit containing one series resistance and three resistance-capacitance $(\mathrm{R}-\mathrm{C})$ parallel circuits was constructed for the $\mathrm{TiO}_{2}$-copper oxides cell, and one series resistance and two $\mathrm{R}-\mathrm{C}$ circuits for the $\mathrm{TiO}_{2}$-platinum cell (Figure 6). The impedance values obtained for these two cells are shown in Table 2.

The impedance values of the interfaces of the electrodes were determined from Nyquist plots (Table 2). The series resistance values were not much different in both cells; this is considered to be the resistance value of the electrolyte solution. RC circuit 1 appears in the equivalent circuit of the $\mathrm{TiO}_{2}$-copper oxides cell, but not in the $\mathrm{TiO}_{2}$-platinum cell. This is due to the effect of the base stainless steel substrate in the copper oxides electrode, since there is no stainless steel substrate in the cathodic counter-electrode (only platinum). Therefore, these impedance values represent the copper oxides-stainless steel interface and the internal circuit resistance. The resistance values of RC circuit 2 are similar; this is due to the effect of the common electrode in both cells-the $\mathrm{TiO}_{2}$ electrode. Therefore, these impedance values represent the electrolyte- $\mathrm{TiO}_{2}$ cathode interface. In RC circuit 3 , the impedance values of the $\mathrm{TiO}_{2}-\mathrm{Cu}$ oxides cell are more than 10 times higher than those of the $\mathrm{TiO}_{2}$-platinum cell. The resistivity of platinum is much lower than that of copper oxides [48]. Since platinum is a noble metal with high electrical conductivity, the increase in the impedance values of $\mathrm{TiO}_{2}-\mathrm{Cu}$ oxides should be the combined represented values for the $\mathrm{Cu}$ oxides electrode-electrolyte (seawater) interface. 


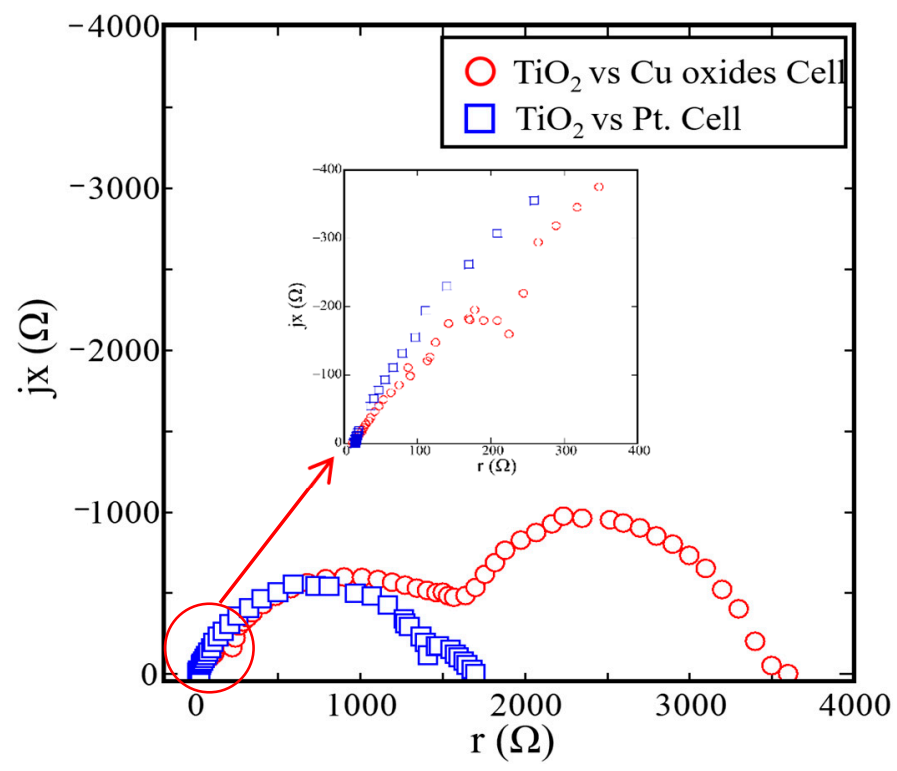

Figure 5. Nyquist plots of two types of electrodes.
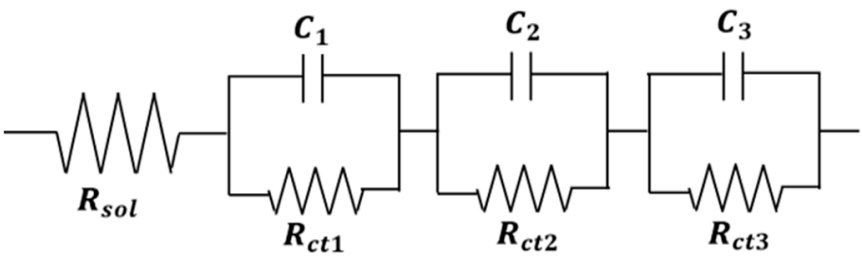

(a)

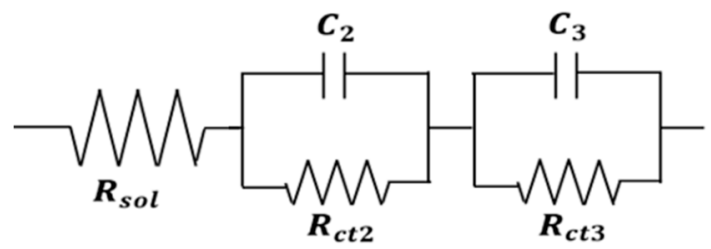

(b)

Figure 6. Equivalent circuits by curve fitting: (a) $\mathrm{TiO}_{2}-\mathrm{Cu}$ oxides cell (b) $\mathrm{TiO}_{2}$-platinum cell.

Table 2. Impedance values of two cells under irradiation.

\begin{tabular}{|c|c|c|c|c|c|c|c|}
\hline \multirow[t]{3}{*}{ Cells } & \multicolumn{7}{|c|}{ Impedance Values } \\
\hline & \multirow{2}{*}{$\begin{array}{c}\text { Series Resistance } \\
\text { Rs }\end{array}$} & \multicolumn{2}{|c|}{ RC Circuit 1} & \multicolumn{2}{|c|}{ RC Circuit 2} & \multicolumn{2}{|c|}{ RC Circuit 3} \\
\hline & & $R_{1}(\Omega)$ & $\mathrm{C}_{1}(\mathrm{mF})$ & $R_{2}(\Omega)$ & $\mathrm{C}_{2}(\mathrm{mF})$ & $R_{3}(\Omega)$ & $\mathrm{C}_{3}(\mathrm{mF})$ \\
\hline $\mathrm{TiO}_{2}-\mathrm{Cu}$ oxides & 15.26 & 156.81 & 0.01 & 1290 & 0.36 & 2180 & 5.36 \\
\hline $\mathrm{TiO}_{2}-$ platinum & 14.03 & & & 1330 & 1.99 & 81.91 & 0.81 \\
\hline
\end{tabular}

\section{Discussions}

From these results, the photopotential values of the titanium dioxide electrode and the copper oxides electrode were found to be stable during the $2 \mathrm{~h}$ measurement, and their cell voltage also remained stable during the $24 \mathrm{~h}$ measurement (Figure 2). The measured cell voltage was around $800 \mathrm{mV}$, which is close to the summation of their standard electrode potential. The potential reduction occurred in the early phase of photopotential measurement of both electrodes. In the $24 \mathrm{~h}$ cell voltage measurement, the decrease in voltage was observed in the first half of the measurement in the $\mathrm{TiO}_{2}-\mathrm{Cu}$ oxides cell. However, there was no decrease in voltage in the measurement of the $\mathrm{TiO}_{2}$-stainless steel cell (Figure 2). This result was related to the copper oxides electrode.

In the XRD patterns shown in Figure 3, the peak of $\mathrm{Cu}_{2} \mathrm{O}$ appeared in the electrode before the photopotential measurement, but it was absent after photopotential measurement. During the heat treatment of deposited copper at $350{ }^{\circ} \mathrm{C}$, the thermal oxidation mechanism of copper takes place in the sequence of $\mathrm{Cu} \rightarrow\left(\mathrm{Cu}+\mathrm{Cu}_{2} \mathrm{O}\right) \rightarrow \mathrm{Cu}_{2} \mathrm{O} \rightarrow\left(\mathrm{Cu}_{2} \mathrm{O}+\right.$ $\mathrm{CuO}) \rightarrow \mathrm{CuO}$. [38] However, there was still $\mathrm{Cu}_{2} \mathrm{O}$ left during the heat treatment of copper for $30 \mathrm{~min}$, depending on the variation in the thickness of the deposited copper film during 
vacuum vapor deposition process. The copper(I) oxide phase underwent oxidation under irradiation in the presence of seawater. This oxidation reaction caused the decrease in the $\mathrm{p}$ type semiconductor photocatalytic effect of the copper oxides electrode and, hence, caused the scattered decrease in cell voltage in the measurement of the $\mathrm{TiO}_{2}$-copper oxides cell.

In the power density vs. cell voltage measurement (Figure 4), the maximum cell power density of the combined $\mathrm{TiO}_{2}-\mathrm{Cu}$ oxides cell was $\sim 6 \mu \mathrm{W} / \mathrm{cm}^{2}$, and this cell efficiency was less than $1 \%$ when the incident light intensity was $10.5 \mathrm{~mW} / \mathrm{cm}^{2}$ (excluding the light-reduction effect of quartz glass). When the two electrodes were separated by $10 \mathrm{~cm}$ (separated $\mathrm{TiO}_{2}-\mathrm{Cu}$ oxides cell) in ASW, the power density was further reduced by more than $20 \%$, to $4.2 \mu \mathrm{W} / \mathrm{cm}^{2}$; this was due to the loss of ion exchange between the electrodes in seawater. Therefore, the use of seawater as the electrolyte is an important factor in the power output of the cell. In the EIS analysis, the impedance values of the electrodes in both the $\mathrm{TiO}_{2}-\mathrm{Cu}$ oxides and $\mathrm{TiO}_{2}$-platinum cells were higher compared to those of dye-sensitized solar cells (DSSCs) [49]. This confirms the loss of charge transfer between electrodes in seawater as an electrolyte.

The maximum power density of the $\mathrm{TiO}_{2}$-platinum cell was the highest among the cells, at $9 \mu \mathrm{W} / \mathrm{cm}^{2}$. On the other hand, the maximum power density of the combined $\mathrm{TiO}_{2}-\mathrm{Cu}$ oxides cell was two-thirds of that of the $\mathrm{TiO}_{2}-$ platinum cell. Considering the cost-to-cell-efficiency ratio, the cost effectiveness of the combined $\mathrm{TiO}_{2}-\mathrm{Cu}$ oxides cell was much higher than that of the $\mathrm{TiO}_{2}$-platinum cell, since the materials and the preparation of the copper oxides electrode required simple processes, and were not costly. This is the reason for using copper oxides electrodes to replace platinum counter-electrodes in the fabrication of marine wet solar cells.

\section{Experimental}

\subsection{Fabrication of the Marine Wet Solar Cell}

For both electrodes, the same type 329J4L stainless steel with a thickness of $1 \mathrm{~mm}$ was used as the base substrate. This stainless steel showed a dual-phase structure of ferrite and austenite. Dual-phase stainless steel is used in marine environments due to its relatively high corrosion resistance compared to other single-phase stainless steels [50]. The composition of type 329J4L stainless steel is shown in Table 3.

Table 3. Chemical composition of type 329J4L stainless steel (mass $\%$ ).

\begin{tabular}{ccccccccccc}
\hline $\mathbf{C}$ & $\mathbf{S i}$ & $\mathbf{M n}$ & $\mathbf{P}$ & $\mathbf{N i}$ & $\mathbf{C r}$ & $\mathbf{M o}$ & $\mathbf{W}$ & $\mathbf{N}$ & $\mathbf{F e}$ \\
\hline 0.025 & 0.44 & 0.77 & 0.027 & 6.34 & 24.96 & 3.22 & 0.14 & 0.27 & Bal. \\
\hline
\end{tabular}

\subsubsection{Preparation of Titanium Dioxide Electrode}

The surface of the substrate was ground with 60-grade sandpaper in the horizontal and transverse directions. After that, the substrate was put in a beaker of acetone and cleaned in an ultrasonic cleaner for $10 \mathrm{~min}$. The substrate was then passivated, and the passivation treatment was performed by placing the substrate in a solution of 10 volume $\%$ nitric acid $\left(\mathrm{HNO}_{3}\right)$. The passivation was carried out on the surface of the substrate to remove active ions from the surface, and to form a thin passive layer, which enhanced the pitting and crevice corrosion resistance of the substrate [51]. The temperature was maintained at $60{ }^{\circ} \mathrm{C}$ for $30 \mathrm{~min}$ for passivation treatment. After passivation, the surface of the passivated substrate was printed with $\mathrm{TiO}_{2}$ paste. $\mathrm{TiO}_{2}$ paste was obtained from Showa Denko (product name-SP-100, reference name-CE-JP930). The composition of the $\mathrm{TiO}_{2}$ paste is shown in Table 4. Two layers of $\mathrm{TiO}_{2}$ were printed with the screen printer. Printing of the first layer was followed by heat treatment at a temperature of $150{ }^{\circ} \mathrm{C}$ for $1 \mathrm{~h}$, after which the electrode was cooled down slowly in the oven. After printing the second layer, the electrode was sintered at a temperature of $550{ }^{\circ} \mathrm{C}$ for $30 \mathrm{~min}$, and then cooled down in ambient conditions. Hence, a thin double-layered $\mathrm{TiO}_{2}$ film of $\sim 120 \mu \mathrm{m}$ thickness was formed on the substrate, forming the $\mathrm{TiO}_{2}$ electrode [40]. 
Table 4. Composition of $\mathrm{TiO}_{2}$ paste (weight \%).

\begin{tabular}{ccccccc}
\hline \multirow{2}{*}{$\mathrm{TiO}_{2}$ Paste } & $\mathrm{TiO}_{2}$ & $\mathrm{C}_{2} \mathrm{H}_{5} \mathrm{OH}$ & $\mathrm{CH}_{3} \mathrm{OH}$ & $\mathrm{C}_{3} \mathrm{H}_{7} \mathrm{OH}$ & Confidential & Water \\
\cline { 2 - 7 } & 16 & $5-15$ & $0-1$ & $0-2$ & $1-10$ & Bal. \\
\hline
\end{tabular}

\subsubsection{Preparation of Copper Oxides Electrode}

The substrate was cleaned and passivated in the same way as the preparation of the $\mathrm{TiO}_{2}$ electrode. The passivated substrate was deposited with pure copper in the vacuum vapor deposition chamber. The conditions for vacuum deposition were $0.4 \mathrm{mPa}$ and a current of $40 \mathrm{~A}$ with 1.3 volts [43]. The thickness of the copper deposited was less than $0.3 \mu \mathrm{m}$. After deposition with pure copper, the substrate was sintered at $350{ }^{\circ} \mathrm{C}$ for $30 \mathrm{~min}$, and it was cooled down in ambient conditions to form a copper oxides (mainly $\mathrm{CuO}$ and $\mathrm{Cu}_{2} \mathrm{O}$ ) film with a thickness of $\sim 0.3 \mu \mathrm{m}$ on the substrate.

\subsubsection{Fabrication of the Cell}

Four types of cells were prepared to distinguish the photocatalytic properties and electrochemical characteristics of $\mathrm{TiO}_{2}$-copper oxides cells, along with each electrode's properties:

1. The first was a separated $\mathrm{TiO}_{2}$-copper oxides cell. In the separated cell, the two electrodes were insulated with epoxy resin separately, and were measured $10 \mathrm{~cm}$ apart in artificial seawater;

2. The second cell was a combined $\mathrm{TiO}_{2}$-copper oxides cell. In this combined cell, the $\mathrm{TiO}_{2}$ electrode and copper oxides electrode were connected using a silicon binder, which acted as an insulator between the electrodes. The cell was covered with epoxy resin in preparation for the measurement;

3. In the third type of cell, the passivated stainless steel substrate was used as the cathodic electrode coupled with the $\mathrm{TiO}_{2}$ electrode $\left(\mathrm{TiO}_{2}\right.$-S.S. cell);

4. The last cell was the $\mathrm{TiO}_{2}$ electrode vs. platinum counter-electrode $\left(\mathrm{TiO}_{2}-\mathrm{Pt}\right.$ cell). A simple illustration regarding the preparation procedure of the electrodes is shown in Figure 7, along with the image of the prepared combined cell.

\subsection{Electrochemical Measurement}

The electrochemical measurement consisted of photopotential measurement of each electrode, cell voltage measurement of the cells, power density-cell voltage $(\mathrm{P}-\mathrm{V})$ measurement of the cells, and electrochemical impedance spectroscopy (EIS) of the cells. Each electrochemical measurement was performed using artificial seawater as the electrolyte. For irradiation measurement, a xenon lamp with a calibrated wavelength range of 250-800 nm and an irradiation intensity of $10.5 \mathrm{~mW} / \mathrm{cm}^{2}$ was used as a light source. A saturated calomel electrode (SCE) was used as a reference electrode. The potentiostat was used for photopotential measurement, and the electrochemical impedance analyzer with a frequency-response analyzer was used for the electrochemical impedance analysis (EIS).

The photopotential measurement for each electrode was performed for $2 \mathrm{~h}$ under irradiation, with an initial 3 min of darkness. Based on the results of the photopotential measurement, the cell voltage measurement was conducted for $24 \mathrm{~h}$. The power density versus cell voltage $(\mathrm{P}-\mathrm{V})$ measurement was carried out under irradiation, within a voltage range from open-circuit voltage $\left(\mathrm{V}_{\mathrm{oc}}\right)$ to short-circuit voltage $\left(\mathrm{V}_{\mathrm{sc}}\right)$. Based on the current obtained from the Tafel region of the P-V curve, EIS measurement was performed in a frequency range from $100 \mathrm{kHz}$ to $1 \mathrm{mHz}$. Figure 8 shows the schematic diagram of electrochemical measurement of each electrode and each cell. 


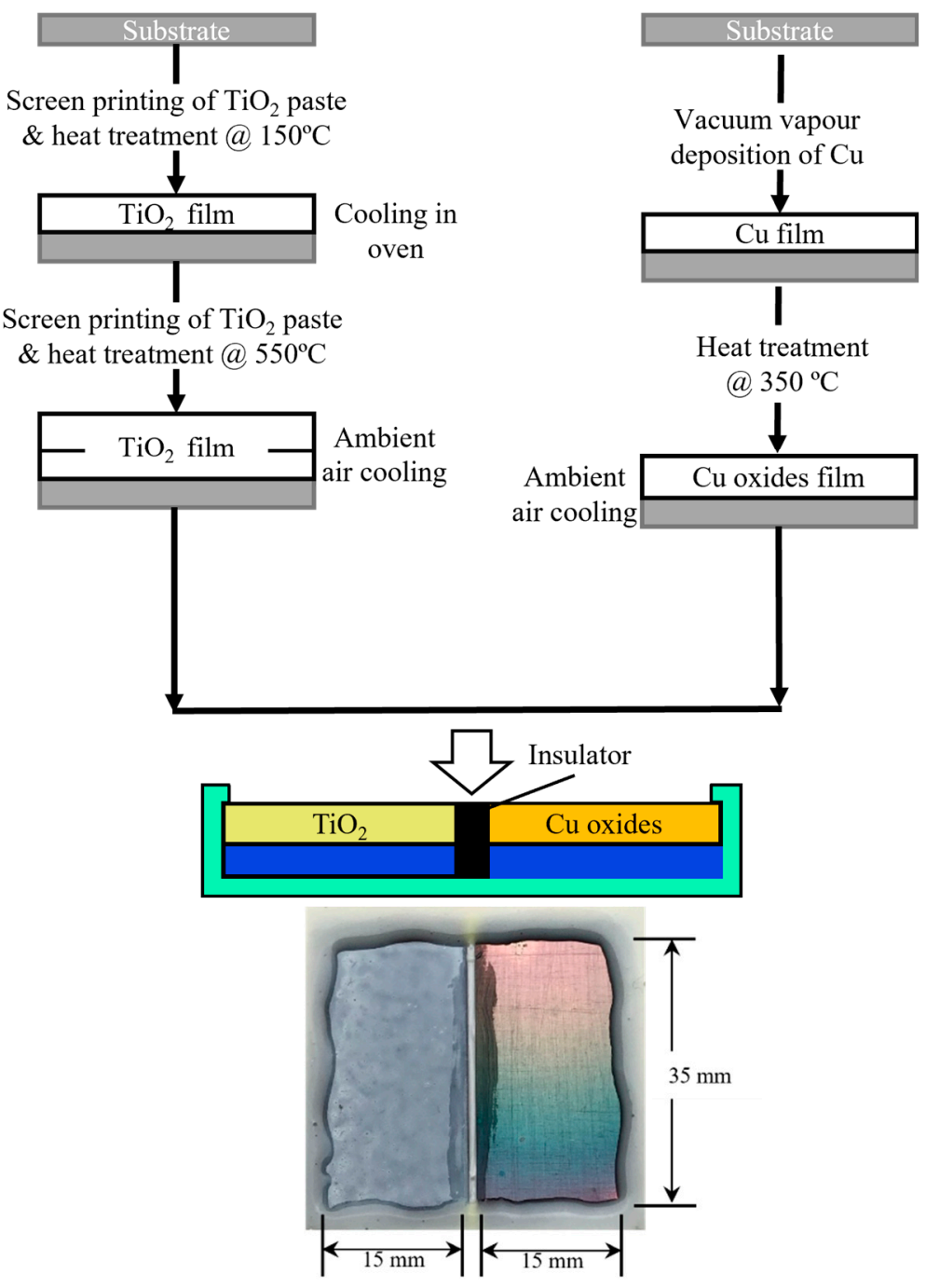

Figure 7. Preparation of each electrode of the $\mathrm{TiO}_{2}$-copper oxides cell, and its image.

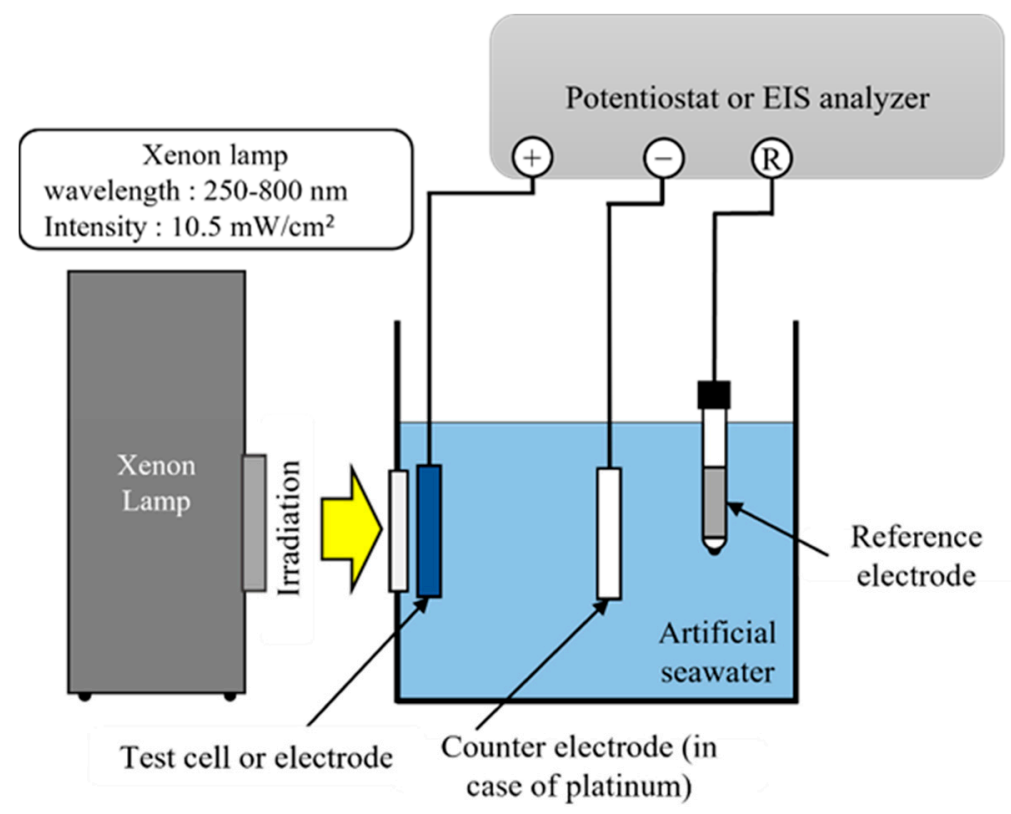

Figure 8. Schematic representation of electrochemical measurement of electrodes and cells. 


\subsection{XRD Analysis of the Electrodes}

X-ray diffraction (XRD) analysis was performed to obtain the phase information of the electrodes. Data on the copper oxides electrode will be used for discussion. For the copper oxides electrode, the analysis was performed for the substrate, the substrate with pure copper deposited, and the copper oxides electrode before and after photopotential measurement. $\mathrm{Cu}-\mathrm{K} \alpha$ radiation with $\lambda=1.54 \AA$ was used as the $\mathrm{X}$-ray source, with an $X$-ray-generating voltage of $40 \mathrm{kV}$ and an emission current of $15 \mathrm{~mA}$.

\section{Conclusions and Perspectives}

This study, to the best of our knowledge, is the first to focus on the fabrication of a low-cost novel marine wet solar cell with a titanium dioxide photoanode and a copper oxides photocathode instead of a platinum counter-electrode The purpose is to effectively utilize the marine environment for the harvesting of light. The photocatalytic properties of the titanium dioxide anode and copper oxides cathode were examined. The respective cell voltage, cell power density, and cell characteristics were measured and analyzed, and the effect of decreasing voltage was studied. The cells' electrochemical properties were examined and evaluated. This research focused on the early phase of study of the marine wet solar cell with seawater as the electrolyte.

1. The measurement of each electrode showed that their photopotential values remained stable, and close to the standard potential of each electrode;

2. The cell voltage of the $\mathrm{TiO}_{2}-\mathrm{Cu}$ oxides cell was stable over $24 \mathrm{~h}$ of measurement, with a few drops in the early hours. The factors affecting that drop were revealed. Some residual $\mathrm{Cu}_{2} \mathrm{O}$ that remained in the $\mathrm{Cu}$ oxides electrode after heat treatment underwent oxidation in the seawater under irradiation. This oxidation led to lower p-type semiconductor photocatalytic activity of the $\mathrm{Cu}$ oxides electrode;

3. We have achieved a power profile of the combined $\mathrm{TiO}_{2}-\mathrm{Cu}$ oxides cell in which the maximum power density was two-thirds of that of the $\mathrm{TiO}_{2}$-platinum cell. This can support the replacement of platinum counter-electrodes with copper oxides electrodes in terms of cost-to-energy-conversion efficiency;

4. From the EIS measurements, the impedance values for the charge-transfer resistance of the semiconductor electrode/electrolyte were evaluated by constructing a simple equivalent circuit. From this, we can consider the preparation techniques and the materials to reduce the resistance of the electrode.

The future perspective of this research is to study the cause of the reduction in photocatalytic effect in $\mathrm{TiO}_{2}$ electrodes, in order to improve the long-term stability and durability of the cell, its practical application, and its impact on the environment.

Author Contributions: Conceptualization, S.M. and M.M.; methodology, S.M., M.M., and H.N.W.; software, H.N.W.; formal analysis, H.N.W.; investigation, H.N.W.; writing—original draft preparation, H.N.W.; writing - review and editing, S.M. and M.M.; supervision, S.M.; funding acquisition, S.M. and M.M. All authors made a significant contribution to the completion of this manuscript. All authors have read and agreed to the published version of the manuscript.

Funding: Part of this research is funded by the Grant-in-Aid for Scientific Research from the Japan Society for the Promotion of Science (JSPS) (No. 26281045), and the 22nd and 27th Research Promotion Grant of the Iron and Steel Institute of Japan (ISIJ) (H25-012 and H27-030).

Data Availability Statement: The data presented in this article are sharable on request to the corresponding author.

Acknowledgments: Part of this manuscript is included in the doctoral dissertation submitted by Author Htoo Nay Wunn to Tokyo University of Marine Science and Technology. The university encouraged the author to submit the manuscript for publication.

Conflicts of Interest: The authors declare no conflict of interest. 


\section{References}

1. Perera, H.D.M.R. Designing of 3MW Floating Photovoltaic Power System and its Benefits over Other PV Technologies. Int. J. Adv. Sci. Res. Eng. 2020, 6, 37-48. [CrossRef]

2. Solomin, E.; Sirotkin, E.; Cuce, E.; Selvanathan, S.P.; Kumarasamy, S. Hybrid Floating Solar Plant Designs: A Review. Energies 2021, 14, 2751. [CrossRef]

3. Sreenath, S.; Sudhakar, K.; Yusop, A.F.; Solomin, E.; Kirpichnikova, I.M. Solar PV Energy System in Malaysian Airport: Glare Analysis, General Design and Performance Assessment. Energy Rep. 2020, 6, 698-712. [CrossRef]

4. Bakranov, N.; Zhabaikhanov, A.; Kudaibergenov, S.; Ibraev, N. Decoration of Wide Bandgap Semiconducting Materials for Enhancing Photoelectrochemical Efficiency of PEC Systems. In Journal of Physics: Conference Series; IOP Publishing: Bristol, UK, 2018; p. 012028. [CrossRef]

5. Fujishima, A.; Honda, K. Electrochemical Photolysis of Water at a Semiconductor Electrode. Nature 1972, 238, 37-38. [CrossRef] [PubMed]

6. O’Regan, B.; Grätzel, M. A Low-Cost, High-Efficiency Solar Cell Based on Dye-Sensitized Colloidal TiO 2 Films. Nature 1991, 353, 737-740. [CrossRef]

7. Fahmi, A.; Minot, C.; Silvi, B.; Causa, M. Theoretical Analysis of the Structures of Titanium Dioxide Crystals. Phys. Rev. B 1993, 47, 11717. [CrossRef]

8. Ding, X.Z.; Liu, X.H.; He, Y.Z. Grain Size Dependence of Anatase-to-Rutile Structural Transformation in Gel-Derived Nanocrystalline Titania Powders. J. Mat. Sci. Let. 1996, 15, 1789-1791. [CrossRef]

9. Smith, S.J.; Stevens, R.; Liu, S.; Li, G.; Navrotsky, A.; Boerio-Goates, J.; Woodfield, B.F. Heat Capacities and Thermodynamic Functions of $\mathrm{TiO}_{2}$ Anatase and Rutile: Analysis of Phase Stability. Amer. Miner. 2009, 94, 236-246. [CrossRef]

10. Ghosh, T.B.; Dhabal, S.; Datta, A.K. On Crystallite Size Dependence of Phase Stability of Nanocrystalline TiO ${ }_{2}$. J. Appl. Phys. 2003, 94, 4577. [CrossRef]

11. Beltran, A.; Gracia, L.; Andres, J. Density Functional Theory Study of the Brookite Surfaces and Phase Transitions between Natural Titania Polymorphs. J. Phys. Chem. B 2006, 110, 23417-23423. [CrossRef]

12. El Goresy, A.; Chen, M.; Dubrovinsky, L.S.; Gillet, P.; Graup, G. An Ultradense Polymorph of Rutile with Seven-Coordinated Titanium from the Ries Crater. Science 2001, 293, 1467-1470. [CrossRef] [PubMed]

13. Muscat, J.; Swamy, V.; Harrison, N.M. First-Principles Calculations of The Phase Stability of TiO 2 . Phys. Rev. B 2002, 65, 224112. [CrossRef]

14. Reyes, C.D.; Rodriguez, G.G.; Espinosa, P.M.E.; Cab, C.; de Coss, R.; Oskam, G. Phase-Pure $\mathrm{TiO}_{2}$ Nanoparticles: Anatase, Brookite and Rutile. Nanotechnology 2008, 19, 145605. [CrossRef]

15. Kalyanasundaram, K.; Bertoz, M.; Bisquert, J.; Angelis, F.D.; Desilvestro, H.; Santiago, F.F.; Fantacci, S.; Hagfeldt, I.S.; Jiang, K.J.; Kamat, P.V.; et al. Dye-Sensitized Solar Cell, 1st ed.; CRC Press, Taylor and Francis Group: Boca Raton, FL, USA, $2010 ;$ pp. 1-76.

16. Hanaor, D.A.H.; Sorrell, C.C. Review of The Anatase to Rutile Phase Transformation. J. Mater. Sci. 2011, 46, 855-874. [CrossRef]

17. Wold, A. Photocatalytic Properties of Titanium Dioxide $\left(\mathrm{TiO}_{2}\right)$. Chem. Mater. 1993, 5, 280-283. [CrossRef]

18. Gratzel, M. Solar Energy Conversion by Dye-Sensitized Photovoltaic Cells. Inorg. Chem. 2005, 44, 6841-6851. [CrossRef]

19. Bessekhouad, Y.; Robert, D.; Weber, J.V. Preparation of $\mathrm{TiO}_{2}$ Nanoparticles by Sol-Gel Route. Int. J. Photoenergy 2003, 5, 153-158. [CrossRef]

20. Baram, N.; Starosvetsky, D.; Starosvetsky, J.; Epshtein, M.; Armon, R.; Ein-Eli, Y. Enhanced Photo-Efficiency of Immobilized TiO 2 Catalyst Via Intense Anodic Bias. Electrochem. Commun. 2007, 9, 1684-1688. [CrossRef]

21. Mitoraj, D.; Janczyk, A.; Strus, M.; Kisch, H.; Stochel, G.; Heczko, P.B.; Macyk, W. Visible Light Inactivation of Bacteria and Fungi by Modified Titanium Dioxide. Photochem. Photobiol. Sci. 2007, 6, 642. [CrossRef]

22. Kisch, H.; Burgeth, G.; Macyk, W. Visible Light Photocatalysis by A Titania Transition Metal Complex. Adv. Inorg. Chem. 2004, 56, 241-259. [CrossRef]

23. Fujino, T.; Matzuda, T. Synthetic Process of Titanium Dioxide Coating on Aluminum by Chemical Conversion Method. Mater. Trans. 2006, 47, 849-853. [CrossRef]

24. León, A.; Reuquen, P.; Garín, C.; Segura, R.; Vargas, P.; Zapata, P.; Orihuela, P.A. FTIR and Raman Characterization of TiO 2 Nanoparticles Coated with Polyethylene Glycol as Carrier for 2-Methoxyestradiol. Appl. Sci. 2017, 7, 49. [CrossRef]

25. Burns, G.P. Titanium Dioxide Dielectric Films Formed by Rapid Thermal Oxidation. J. Appl. Phys. 1989, 65, 2095. [CrossRef]

26. Mittiga, A.; Salza, E.; Sarto, F.; Tucci, M.; Vasanthi, R. Heterojunction Solar Cell with $2 \%$ Efficiency Based on a Cu ${ }_{2} \mathrm{O}$ Substrate. Appl. Phys. Lett. 2006, 88, 163502. [CrossRef]

27. Minami, T.; Miyata, T.; Ihara, K.; Minamino, Y.; Tsukada, S. Effect of ZnO Film Deposition Methods on the Photovoltaic Properties of $\mathrm{ZnO}-\mathrm{Cu}_{2} \mathrm{O}$ Heterojunction Devices. Thin Solid Films 2006, 494, 47-52. [CrossRef]

28. Wong, L.M.; Chiam, S.Y.; Huang, J.Q.; Wang, S.J.; Pan, J.S.; Chim, W.K. Growth of $\mathrm{Cu}_{2} \mathrm{O}$ on Ga-doped ZnO and Their Interface Energy Alignment for Thin Film Solar Cells. J. Appl. Phys. 2010, 108, 033702. [CrossRef]

29. Raizada, P.; Sudhaik, A.; Patial, S.; Hasija, V.; Khan, A.A.P.; Singh, P.; Gautam, S.; Kaur, M.; Nguyen, V.H. Engineering Nanostructures of CuO-Based Photocatalysts for Water Treatment: Current Progress and Future Challenges. Arab. J. Chem. 2020, 13, 8424-8457. [CrossRef]

30. Narayanan, R.; El-Sayed, M.A. Catalysis with Transition Metal Nanoparticles in Colloidal Solution: Nanoparticle Shape Dependence and Stability. J. Phys. Chem. B 2005, 109, 12663-12676. [CrossRef] [PubMed] 
31. Kumar, K.Y.; Muralidhara, H.B.; Nayaka, Y.A.; Hanumanthappa, H.; Veena, M.S.; Kumar, S.R. Hydrothermal Synthesis of Hierarchical Copper Oxide Nanoparticles and Its Potential Application as Adsorbent for Pb (II) with High Removal Capacity. Sep. Sci. Technol. 2014, 49, 2389-2399. [CrossRef]

32. Verma, N.; Kumar, N. Synthesis and Biomedical Applications of Copper Oxide Nanoparticles: An Expanding Horizon. Biomater. Sci. Eng. 2019, 5, 1170-1188. [CrossRef]

33. Pavan, M.; Ruhle, S.; Ginsburg, A.; Keller, D.A.; Barad, H.N.; Sberna, P.M.; Nunes, D.; Martins, R.; Anderson, A.Y.; Zaban, A.; et al. $\mathrm{TiO}_{2} / \mathrm{Cu}_{2} \mathrm{O}$ All-Oxide Heterojunction Solar Cells Produced by Spray Pyrolysis. Sol. Energy Mater. Sol. Cells 2014, 132, 549-556. [CrossRef]

34. Armelao, L.; Barreca, D.; Bertapelle, M.; Bottaro, G.; Sada, C.; Tondello, E. A Sol-Gel Approach to Nanophasic Copper Oxide Thin Films. Thin Solid Films 2003, 442, 48-52. [CrossRef]

35. Kosugi, T.; Kaneko, S. Novel Spray-Pyrolysis Deposition of Cuprous Oxide Thin Films. J. Am. Ceram. Soc. 1998, 81, 3117-3124. [CrossRef]

36. Heiroth, S.; Ghisleni, R.; Lippert, T.; Michler, J.; Wokaun, A. Optical and Mechanical Properties of Amorphous and Crystalline Yttria-Stabilized Zirconia Thin Films Prepared by Pulsed Laser Deposition. Acta Mater. 2011, 59, 2330-2340. [CrossRef]

37. Ogale, S.B.; Bilurkar, P.G.; Mate, N.; Kanetkar, S.M. Deposition of Copper Oxide Thin Films on Different Substrates by Pulsed Excimer Laser Ablation. J Appl. Phys. 1992, 72, 3765. [CrossRef]

38. Choudhary, S.; Sarma, J.V.N.; Pande, S.; Girard, S.A.; Turban, P.; Lepine, B.; Gangopadhyay, S. Oxidation Mechanism of Thin Cu Films: A Gateway Towards the Formation of Single Oxide Phase. AIP Adv. 2018, 8, 055114. [CrossRef]

39. Ito, S.; Chen, P.; Comte, P.; Nazeeruddin, M.K.; Liska, P.; Pechy, P.; Gratzel, M. Fabrication of Screen-Printing Pastes from TiO 2 Powders for Dye-Sensitized Solar Cells. Prog. Photovolt. Res. Appl. 2007, 15, 603-612. [CrossRef]

40. Motoda, S.; Morita, M.; Tamura, S. Characteristics of Double Layered $\mathrm{TiO}_{2}$ Anode Assembling to Marine Microbial Fuel Cell. ECS Trans. 2017, 75, 133-143. [CrossRef]

41. Alami, A.H.; Rajab, B.; Abed, J.; Faraj, M.; Hawili, A.A.; Alawadhi, H. Investigating Various Copper Oxides-Based Counter Electrodes for Dye Sensitized Solar Cell Applications. Energy 2019, 174, 526-533. [CrossRef]

42. Shibata, M.; Sakai, Y.; Yokoyama, D. Advantages and Disadvantages of Vacuum-Deposited and Spin-Coated Amorphous Organic Semiconductor Films for Organic Light-Emitting Diodes. J. Mater. Chem 2015, 3, 11178-11191. [CrossRef]

43. Morita, M.; Kishihara, K.; Motoda, S.; Koga, N.; Shinohara, T. Effect of Oxidation Temperature on Photo-Catalytic Properties of Stainless Steel Coated by Copper Oxide. ISIJ Int. 2017, 57, 1609-1616. [CrossRef]

44. Raja, M.; Subha, J.; Ali, F.B.; Ryu, S.H. Synthesis of Copper Nanoparticles by Electroreduction Process. Mater. Manuf. Processes 2008, 23, 782-785. [CrossRef]

45. Mehmood, U.; Aslam, H.M.Z.; Sulaiman, F.A.A.; Ahmed, A.A.; Ahmed, S.; Malik, M.I.; Younas, M. Electrochemical Impedance Spectroscopy and Photovoltaic Analyses of Dye-Sensitized Solar Cells Based on Carbon/ $\mathrm{TiO}_{2}$ Composite Counter Electrode. J. Electrochem. Soc. 2016, 163, H339. [CrossRef]

46. Itagaki, M.; Suzuki, S.; Shitanda, I.; Watanabe, K. Electrochemical Impedance and Complex Capacitance to Interpret Electrochemical Capacitor. Electrochemistry 2007, 75, 649-655. [CrossRef]

47. Sarker, S.; Ahammad, A.J.S.; Seo, H.W.; Kim, D.M. Electrochemical Impedance Spectra of Dye-Sensitized Solar Cells: Fundamentals and Spreadsheet Calculation. Int. J. Photoenergy 2014, 2014, 851705. [CrossRef]

48. Valladares, L.D.L.S.; Salinas, D.H.; Dominguez, A.B.; Najarro, D.A.; Khondaker, S.I.; Mitrelias, T.; Barnes, C.H.W.; Aguiar, J.A.; Majima, Y. Crystallization and Electrical Resistivity of $\mathrm{Cu}_{2} \mathrm{O}$ and $\mathrm{CuO}$ Obtained by Thermal Oxidation of $\mathrm{Cu}$ Thin Films on $\mathrm{SiO}_{2} / \mathrm{Si}$ Substrate. Thin Solid Films 2012, 520, 6368-6374. [CrossRef]

49. Saadmim, F.; Forhad, T.; Sikder, A.; Ghann, W.; M Ali, M.M.; Sitther, V.; Ahammad, A.J.S.; Subhan, M.A.; Uddin, J. Enhancing the Performance of Dye Sensitized Solar Cells Using Silver Nanoparticles Modified Photoanode. Molecules 2020, 25, 4021. [CrossRef] [PubMed]

50. Featured Products, NAS Stainless Steel Strip MFG. Co., Ltd. Available online: http://www.nas-kotai.co.jp/en/leaflet/354n.html\# (accessed on 3 October 2021).

51. Noh, J.S.; Laycock, N.J.; Gao, W.; Wells, D.B. Effects of Nitric Acid Passivation on the Pitting Resistance of 316 Stainless Steel. Corros. Sci. 2000, 42, 2069-2084. [CrossRef] 